頭頸部腫瘤の内部エコーヒストグラムの検討

一第 2 報一

緒方 洋一・関谷透・野口 高昭

增満 洋一.下郡 博明・岡崎 英紀

\title{
Evaluation of Internal Echo Histograms of Head and Neck Tumors (II)
}

\author{
Yoichi Ogata, Toru Sekitani, Takaaki Noguchi, \\ Yoichi Masumitsu, Hiroaki Shimogori and Hideki Okazaki \\ (Yamaguchi University)
}

In order to obtain ultrasonic clues for the differential diagnosis of tumors, we evaluated the internal echo histograms of 23 cases with head and neck tumors (14 malignant and 9 benign) with respect to standard deviation (SD) of the echo level and width of the histograms at $0 \%, 25 \%, 50 \%, 75 \%$ frequency.

1) The average SD of the echo level of the malignant tumors was 8.2 , which was significantly greater than that of the benign tumors $(\mathrm{p}<0.01)$.

2) An analysis of the width of the histograms showed three patterns: bell type with wide base and sides for the malignant tumors, mountain type with a wide base for the benign tumors and mountain type with a narrow base for normal tissue.

It was concluded that we can obtain objectively significant ultrasonic information from the SD of echo levels and the width of histograms for the differential diagnosis between benign and malignant tumors of the head and neck.

Key words: head and neck tumors, internal echo histograms, standard deviation, width of histograms

\section{はじめに}

超音波診断装置の改良は目覚ましく, 分解能 の向上に伴い, 特に内部エコーから得られる情 報量が増している11. しかし Bモード法による 内部エコーは一般に均一及び不均一と判定され, 良性・悪性の鑑別を行っているが，経験的なイ メージのパターン認識に頼っているため, 判断 に苦慮することも少なくない。
そこで我々は超音波画像のヒストグラム法を 用い, 内部ェコー強度の分布を定量的に数值化 し，客観的な表現を試みている。

前回の論文2) では，ヒストグラム幅と最多階 調エコーレベルの 2 点を比較検討したが，その 際ェコーレベル自体の比較には諸条件による問 題があるため，エコーレベルを加味せず，ヒス トグラム幅のみからパターン分類を行い, 報告 
した。

今回は新たにェコーレベルの標準偏差につい ての検討を加え，ヒネトグラム幅と併せて内部 エコーの不均一性を表現した上で, 頭頸部腫瘤 に対する良性・悪性の鑑別を比較検討した。

\section{対 象}

1989年 4 月から1990年 2 月まで，当院で超音 波検査を施行し, 病理組織学的診断を得た頭頸 部腫瘤23例を対象とした．表 1 のごとく，良性 腫瘍 9 例, 悪性腫瘍14例である.

前回同様，cystを形成しているもの，それ に類似のcystic echoを含む腫瘍あるいは石灰
化を伴う腫瘍は全て除外し，超音波画面上で充 実性の腫瘍と考光られたもののみを対象とした。

\section{方法}

使用した装置は Aloka 製 model SSD-630, $7.5 \mathrm{MHz}$ セクタスキャナである。な拉，Gain は80に設定し, STC (sensitivity time control) は全て一定とした。関心領域 (region of interest； ROI) は腫瘍をトレースして設定し， ヒストグラムを作製, 標準偏差 (standard deviation； SD) 抌よびヒストグラム幅を測定し た.

エコーレベルの標準偏差は図 1 のごとく, 得

表 1 対 象

今回検討した頭頸部腫瘤の病理組織学的分類

\begin{tabular}{|c|c|c|c|c|c|}
\hline 良 & 腫 瘍 & & 悪 & 性 腫 瘍 & \\
\hline \multirow[t]{3}{*}{ 耳下腺腫瘍 } & 多型腺腫 & 3 & 耳下腺腫瘍 & 腺様霊胞癌 & 1 \\
\hline & 腺リンパ腫 & 2 & & 粘表皮腫瘍 & 1 \\
\hline & 単一型腺腫 & 1 & 甲状腺腫瘍 & 乳頭腺癌 & 3 \\
\hline \multirow{5}{*}{$\begin{array}{l}\text { 甲状腺腫瘍 } \\
\text { 頸部腫瘤 } \\
\text { 副咽頭間隙腫瘍 }\end{array}$} & 濾胞腺腫 & 1 & & 扁平上皮癌 & 1 \\
\hline & 血管㣫 & 1 & *中咽頭腫瘍 & 扁平上皮癌 & 3 \\
\hline & 神経鞘腫 & 1 & *下咽頭腫瘍 & 扁平上皮癌 & 2 \\
\hline & & & 吅侯頭腫瘍 & 扁平上皮癌 & 1 \\
\hline & & & *舌腫瘍 & 扁平上皮癌 & 2 \\
\hline & & 9 例 & (*頸部リンパ & 筑転移) & †14例 \\
\hline
\end{tabular}

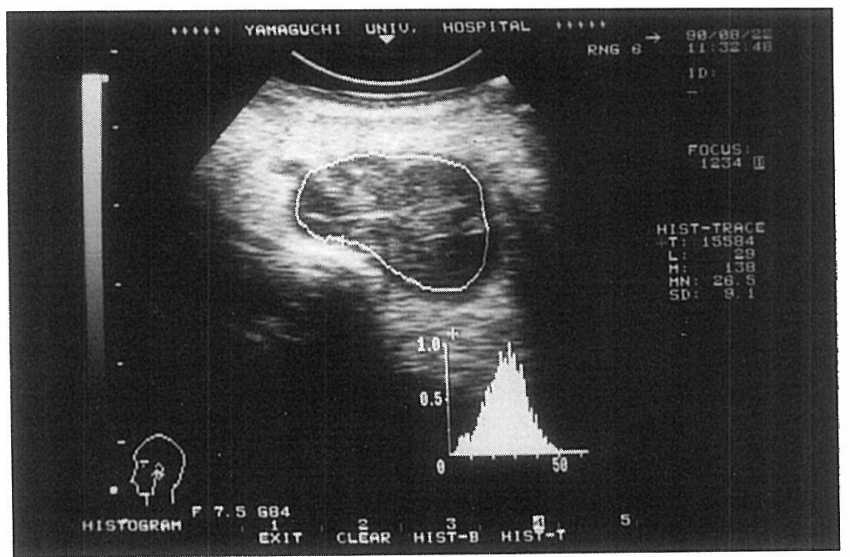

図 1 エコーレベルの標準偏差(SD)は, 内蔵のコンピュータ で処理, 算出される. 右側中央に表示. 
られたヒストグラムより内蔵のコンピュータで 処理され, 算出されたものを用いた. 今回はエ コーレベルは絶対的な数值ではないとの考学か ら, エコーレベル自体の数值は用いず, ヒスト グラムに拈ける標準偏差そのものを検討した. 得られた標準偏差は内部ェコーの不均一性を表 現するひとつの指標として扱い，その值自体を 比較検討した.

ヒストグラム幅は前回の報告2) 同様， $0 \%$, 25\%，50\%，75\%頻度に持けるとれぞれのエコ ーレベルの幅を計測した(図2).

\section{結果}

1) エコーレベルの標準偏差について

良性腫瘍, 悪性腫瘍別に得られたヒストグラ ムのエコーレベルから標準偏差を求め, その平 均値を表 2 亿示した。 な拝, 正常組織群として 健常者10名のそれぞれの甲状腺 $(\mathrm{n}=10)$, 顎下 腺 $(n=10)$, 耳下腺 $(n=10)$ の標準偏差を計測 した。

悪性腫瘍の標準偏差は平均 8.2 , 良性腫瘍の 標準偏差は平均 7.2 と, 悪性腫瘍は良性腫瘍に 比べて，有意に大きな值を示した $(\mathrm{p}<0.05)$. 悪性腫瘍の内部エュー輝度は, 良性腫瘍のそれ と比し, 散らばりがあることが示唆された。

逆に正常組織の標準偏差はさらに小さく, 腫 瘍に比べて, 内部ェコー輝度の散らばりが少な

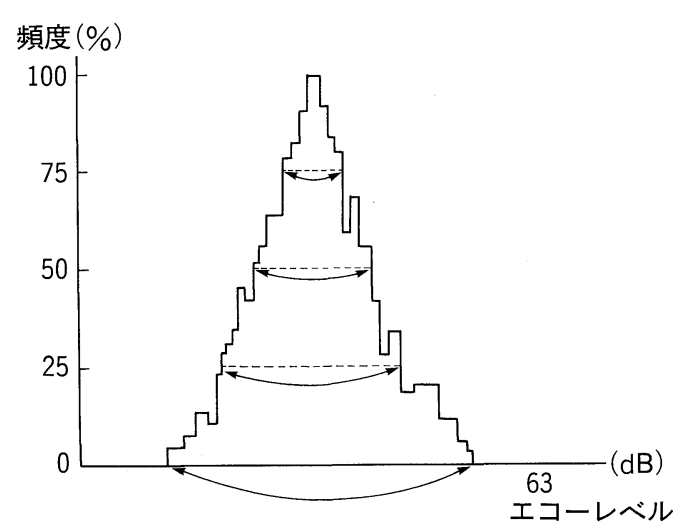

図 2 計測したヒストグラム幅 ( $0 \%, 25 \%, 50 \%, 75 \%$ 各頻度に拈けるヒス トグラム幅)
く、より均一なェューであると推測された。

2) ヒストグラム幅について

良性腫瘍, 悪性腫瘍, 正常組織群別に得られ たヒストグラムの $0 \% ， 25 \% ， 50 \% ， 75 \%$ 頻度 に执けるエコーレベルの幅を図 3 に示寸.

$0 \%$ 頻度(いわゆるヒストグラムの裙野)にお いては正常組織に比べ, 良性腫瘍・悪性腫瘍と もに有意に幅広いヒストグラムを形成した $(\mathrm{p}<0.01)$ ％頻度があがるにつれ，いわゆる ヒストグラムの中腹に向からにつれ，良性腫瘍 は正常組織と比べてそれぞれの\%頻度に叔ける ヒストグラム幅に有意差がなくなってくるが， 悪性腫瘍はヒストグラムの裾野・中腹ともに有 意に幅広いヒストグラムを形成していた $(\mathrm{p}<$ 0.05)。つまり良性腫瘍のヒストグラムは裾野 の広い山型を, 悪性腫瘍は裾野・中腹ともに広 いベル型を呈することが推定され，前回とほぼ 同様の結果が得られた.

\section{考察}

超音波診断法の客観的評価のひとつとしてエ コーレベルの数值化が試みられるようにな $\eta^{3) \sim 5)}$, 我々は前回, 頭頸部腫瘤に対し, ヒス トグラムのパターン分類を行い, 良性・悪性の 鑑別を試案した ${ }^{2)}$. 頭頸部腫瘤の超音波像を定 量的に表現する試みの中で，ヒストグラム幅と 最多階調エコーレベルを比較検討したが，エ コーレベル自体の比較には諸条件による問題が あるため，エコーレベルを加味せず，ヒストグ ラム幅のみからパターン分類を行った。

表 2 エコーレベルの標準偏差 $(\mathrm{SD})$ の比較 悪性腫瘍の標準偏差は良性腫瘍と比べて, 有意に大きな值を示した $(\mathrm{p}<0.05)$.

\begin{tabular}{|c|c|c|c|c|c|}
\hline & \multicolumn{3}{|c|}{ 正常組織群 } & \multicolumn{2}{|l|}{ 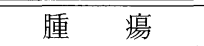 } \\
\hline & $\begin{array}{c}\text { 甲状腺 } \\
(\mathrm{n}=10)\end{array}$ & 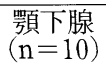 & $\begin{array}{c}\text { 耳下腺 } \\
(\mathrm{n}=10)\end{array}$ & $\begin{array}{l}\text { 良 性 } \\
(\mathrm{n}=9)\end{array}$ & 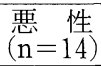 \\
\hline $\mathrm{SD}$ & 6.2 & 6.1 & 5.3 & 7.2 & 8.2 \\
\hline
\end{tabular}


エコーレベルは検査対象となる各蔵器からの 超音波の反射波の強さを幾つかの階調に分類し たものであり，プローベから対象蔵器までに介 在する組織の違いやプローベから測定する臓器 までの距離によって変化する6)。 また施設や検 者によっては設定する Gain が異なったりする ため，図 4 のごとく，条件によってはヒストグ ラムは左右へ平行移動してしまう。つまり土 コーレベルは絶対的な数值ではなく，エコーレ ベル自体の比較はできない。そこでヒストグラ ムの形状をより客観的に評価するために，エ コーレベルの標準偏差を用い，末た前回同様ヒ ストグラム幅の検討を加えることにより，各々 の関心領域に拈いて同じ割合を占めるエコーレ ベルの分布を比較検討した。

その結果，悪性腫瘍の標準偏差は良性腫瘍よ り有意の差をもって大きな值を示した。これは 悪性腫瘍は良性腫瘍より，腫瘍内部の壊死巣や 線維性増殖が強かったりなど，不規則な組織構
築のため超音波が不均一な反射，散乱，減衰を 示すためではないかと考えられる。正常組織群 の標準偏差は5.3〜 6.2 腫瘍に比べ，明らかに 小さく，ヒストグラムの“散らばり”がその均 一性を示唆しているのではないかと思われる。

ヒストグラム幅については前回とほぼ同様の 結果が得られた。悪性腫瘍は裾野・中腹ともに 広いベル型を，良性腫瘍は裾野の広い山型を， 正常組織群は裾野の狭い山型のヒストグラムを 形成すると考えられた。ヒストグラム幅はヒス トグラム各階調の一定頻度に拈ける分布割合を 表しているものであり，標準偏差と同様，各エ コーレベルの分布の不均一性を示す指標といえ る.

この 2 指標の検討をもとに頭頸部腫瘤の良性 - 悪性の鑑別として，図５のような分類を行っ た。症例数に偏りがあるため，今回標準偏差を あくまで高低で示したが，今後症例を集積する ことにより，基準值が定まってくるのではない

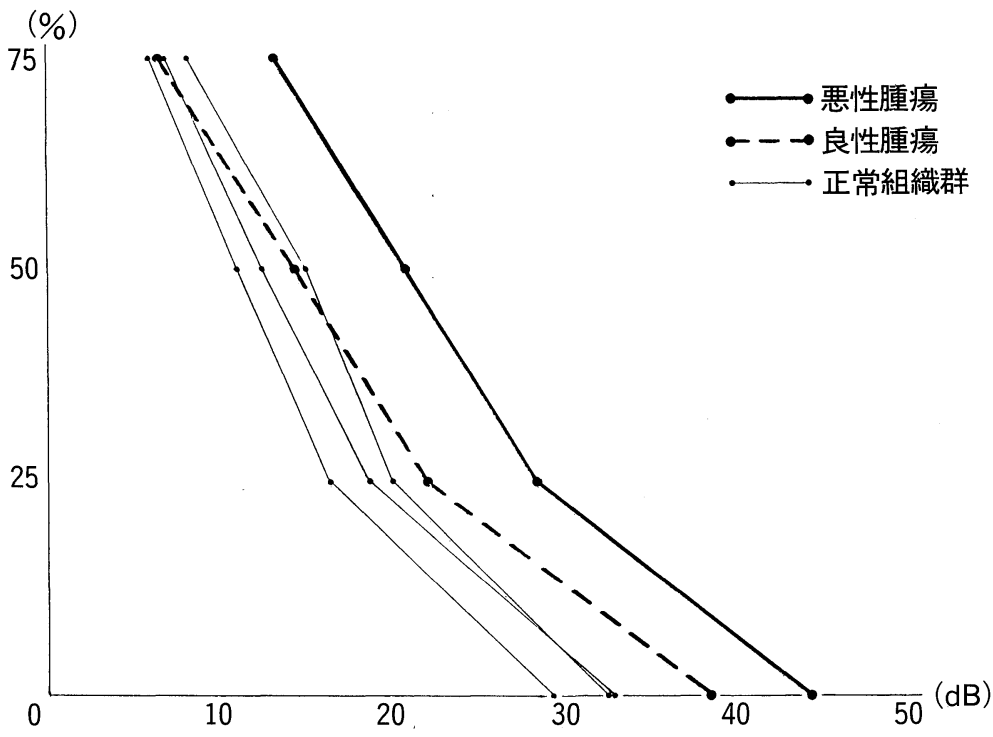

図 3 ヒストグラム幅の比較

覀性腫瘍，良性腫瘍，正常組織別に得られたヒストグラムの0\%，25\%，50\%， 75\%頻度に拈けるェコーレベル幅の平均値をプロットした。細い実線三本の正 常組織群は右が顎下腺, 左が耳下腺, 中央が甲状腺を示す。 $0 \%$ 頻度に括ける ヒストグラム幅の平均値は, 悪性腫瘍が $44.4 \mathrm{~dB}$, 良性腫瘍が $38.6 \mathrm{~dB}$, 顎下 腺 $33.0 \mathrm{~dB}$, 甲状腺 $32.7 \mathrm{~dB}$ ，耳下線 $29.3 \mathrm{~dB}$ であった. 
かと期待している.

ヒストグラムはエュー強度の不均一性を表現 するものであり，必ずしも画像の不均一性を示 寸ものではない5)。その意味でも従来の超音波 診断基準から求められる超音波像のイメージは 良性・悪性の鑑別に必須のものである。乙かし 典型例を除いた症例に拈ける診断では客観的な
評価による情報の意義は大きい，今後ヒストグ ラムによる内部ェコーの解析は従来の診断基準 の補助診断として活躍するのではないだろらか。

$$
\text { まとめ }
$$

1. 頭頸部腫瘤23例から得られた内部エコー ヒストグラムをエューレベルの標準偏差及びヒ ストグラム幅について解析し，それぞれを良性

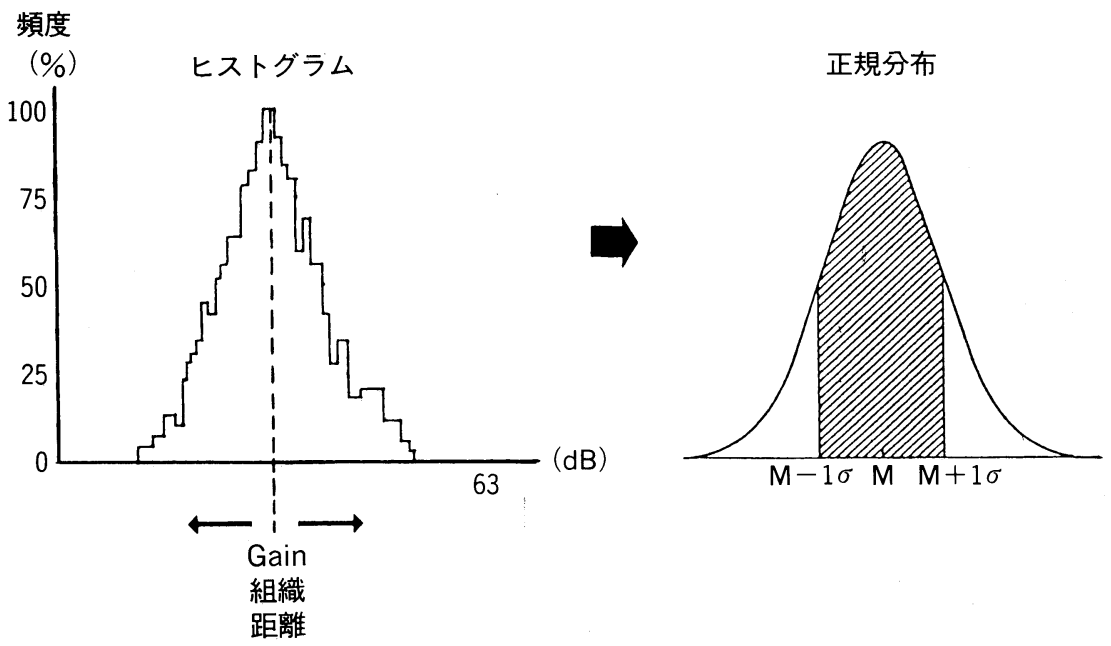

図 4 エコーレベルの標準偏差

エコーレベルは対象臓器までに介在する組織の違いや距離，設定する Gain の違いに より変化するため, 標準偏差による検討を行い, ェコーレベルの不均一性を比較した。

悪性腫瘍

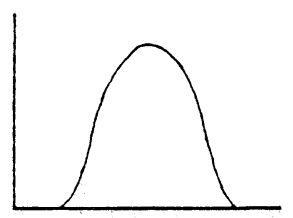

ベル型

$(S D=8.2)$

(裾野44.4dB)
良性腫瘍

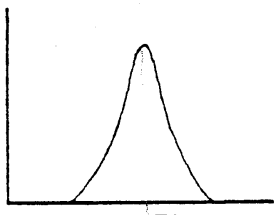

山型

$(S \mathrm{D}=7.2)$

(裾野38.6dB)
正常組織群

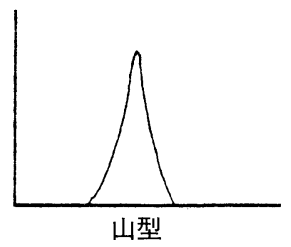

(S D $=5.3 \sim 6.2$ )

(裾野29.3 33.0dB)

図 5 ヒストグラムのパターン分類

悪性腫瘍：裾野，中腹ともに広いベル型 標準偏差が高い

良性腫瘍: 裾野の広い山型 標準偏差が低い

正常組織群: 裾野の狭い山型 標準偏差がさらに低い 
腫瘍，悪性腫瘍別に比較検討した上でその鑑別 の可能性を考察した.

2.エコーレベルの標準偏差は悪性腫瘍で平 均 8.2 之有意飞高く, 良性腫瘍で平均 7.2 , 正常 組織群で5.3〜6.2であった。

3. ヒストグラム幅の検討からヒストグラム を悪性腫瘍は裾野・中腹ともに広いベル型，良 性腫瘍は裾野の広い山型, 正常組織群は裾野の 狭い山型の 3 つのパターンに分類した.

\section{文献}

1）緒方洋一, 野口高昭, 関谷 透: 耳下腺腫瘍の 超音波診断基準の検討. 耳鼻臨床 $82 ： 1269$ 1273, 1989.

2）緒方洋一, 関谷 透, 野口高昭: 頭頸部腫瘤の 内部エコーヒストグラムの検討. 耳鼻臨床 83 : 923 929, 1990.
3）白杵尚志, 三角俊毅, 吉沢順一, 他 : Histogram を用いた肝腫瘍 Echo-level の標準偏差値 の検討. 日超医論文集 $50: 237 \sim 238,1987$.

4）本庄展子, 渡辺敬子, 三浦 融, 他: Histogram を用いた肝・膵の Echo-level の検討. 日 超医論文集 $46: 645 \sim 646,1985$.

5）田中 徹, 杉山義樹, 花沢喜三郎, 他 : ヒス卜 グラムを用いたェコーパターンの定量的表現の 試み. 日超医論文集 $51 ： 251 \sim 252,1987$.

6）臼杵尚志, 吉沢順一, 平井俊一, 他 : Histogram を用いた肝腫瘍 Echo-level の標準偏差の 検討（第 2 報）。 日超医論文集 $51 ： 825 \sim 826$, 1987.

$\left.\begin{array}{l}\text { 原稿受付: 平成 } 2 \text { 年 } 10 \text { 月 } 25 \text { 日 } \\ \text { 原稿採択 : 平成 } 2 \text { 年 } 11 \text { 月 } 9 \text { 日 } \\ \text { 別刷請求先 : 緒方洋一 } \\ \text { 勇 } 755 \text { 宇部市小串 } 1144 \\ \text { 山口大学医学部耳鼻咽喉科学教室 }\end{array}\right)$

